\section{HEALTH WEEK DEVELOPMENTS} $\mathrm{BY}$

Professor A. Bostock Hill, M.D., M.Sc. Tempora mutantur et nos mutamur in illis.

Perhaps there is no better illustration of this than in the modern conception of health work. In the early days of sanitary administration, matters dealt with were chiefly technical, now the main idea is to get the people themselves to understand that to a large extent at least, they must co-operate with the authorities and their skilled advisers if reasonably good results are to be obtained. Health work is largely associated with the home, and both parents and children must be made to appreciate how much depends on their own efforts.

This being so, it is easy to understand how "Health Week" and "Baby Week" came into being, as during the celebrations efforts are made to teach the public the importance of Self-help in Health. This phrase has been adopted as the motto of Health Week, and well expresses the ideal of its promoters. Of late, unhappily, certain difficulties have arisen owing to local troubles in baving the two celebrations in one year. If the first has been successful the second has been hailed with less enthusiasm.

Effort, have been made therefore by the two Committees concerned to work harmoniously in the future, and while it is hoped that the national celebration of Baby Week in London, in July, will be maintained, it is suggested that in the Provinces, and particularly in the smaller towns and country districts joint celebrations should take place later in the year. Health Week is fixed for October, and although it is not absolutely essential that all districts should observe the same date, yet it is desirable that as far as possible the powerful effect of massed effort should be utilized. In many counties and towns the Health Committees and Officials bave taken part in organizing the work, and ample testimony is available as to the value of the results achieved. In other places, little or no support has b:en given, probably from the mistaken idea that the work may possibly conflict in some way with the official administration. Nothing is further from the fact. Health Week and Baby Week prepare the ground for the official tilling and render easier the work which must be done before a real and ample harvest can be gathered.

\section{ANTE-NATAL AND POST-NATAL SYPHILIS.* \\ $\mathrm{BY}$ \\ JOHY ADAMS, F.R.C.S.,}

Medical Officer, Thavies Inn V.D. Centre for Pregnant Women and Newly-born Children; Senior Surgeon, Sheffield Street V.D. Hospital for Women ; Consulting V.D. Surgeon, St. Margaret's Hospital, N.W.

Having shown you a few of the patients who have been treated so that you might better understand what can be done and what ought to be done for this bitherto terrible disease of Ante and Post-Natal Syphilis, I propose to give you details of my research, observation and treatment of this particular section of Syphilis.

History.

It will be interesting to give a short history o congenital syphilis.

It was observed as long ago as 1528 by Paracelsus, 35 years after syphilis was introduced into Europe. If one were asked if we could state when 99 out of 100 of the diseases we are familiar with were first observed, the answer would be in the negative, but we are able to estabish with a certainty the year when syphilis was introduced into Europe.

\section{History of Syphilis.}

Columbus returned from his voyage of discovery to America and landed in Barcelona, 1493. The following year syphilis spread over Europe in a violent form as new diseases usually do. It has been suggested that syphilis was described by Moses in Leviticus, chap. xiii., but the loss of hair and white reddish eruption on head here mentioned, refers to a leprous man, and after reading further, it will be seen that there is no reason to disagree with the opinion of Moses who describes the case.

In Egypt bone lesions have been found in prehistoric coffins with erosions resembling syphilis, and for a time they were considered to be due to that disease, but Elliot Smith, the famous Egyptologist, has proved beyond question that the erosion was caused by a beetle.

In the Greeco-Roman period, A.D. 200 years Sir Clifford Allbutt, writing in a recent work, states that there is nothing to justify the statement that syphilis existed at that period. Later, during the decline of the Roman Empire (A.D. 400) where every kind of vicious living and sensual immorality was practised, syphilis was not mentioned. Some

* Paper read before the Society of Medical Officers of Health. 